\title{
The Effects on Competition of Market Dominance, the Case of T-Bills in Albania
}

\section{Pajtim Melani}

MBA, PhD Candidate, Albanian Competition Authority, Tirana, Albania pajtimmelani2009@yahoo.com tel+355682088603,

\section{Prof. Assoc. Dr. Rezana Konomi}

Albanian Competition Authority, Tirana, Albania rezana.konomi@caa.gov.al

\section{Doi:10.5901/mjss.2013.v4n9p754}

\section{Abstract}

It is generally accepted that competition in the banking system, although is measured by the same indicators as in other markets, should be considered with caution due to inversability that has with that financial stability and due to the chain effect that has to the real economy. But this "excessive" caution for banks should not establish conditions for the future to abuse market position by infringing the principles of free competition and the rules of ethical conduct for competitors and customers. Due to the past historical dominance of the former Savings Bank, inherited a healthy portfolio of banking system deposits, with more than $40 \%$ of the market, a theory accepted limit level to dominate the market. Modern competition legislation does not prohibit per se having a dominant position, but prohibits the abuse of that position and the hypothesis of this paper, will be exactly linked with abuse (or not) to Raiffeisen Bank dominant position in the treasury bond market in Albania.

Keywords: competition, bank, antitrust, tbill, dominance, banking stability

\section{Research objectives}

The banking sector as one of the main sectors of a country's economy has been subject to regulation because of its importance concerning consumer protection and to the weight it has for the economy and its stability. In most countries, the competition policy has been introduced later than the regulation framework, while in Albania in fact, the competition in the banking sector was basically established after the banking sector has been liberalized in 1992 (from one level with a state bank to the modern banking system, one central bank and numerous of commercial banks.

Despite the interventions of the Antitrust Authority in order to establish a free and effective competition in this sector, still seems that much remains to be done in terms of interrelation and balance between competition and regulation.

The concern is mostly related to the fact that regulation in many cases can act as a barrier to competition and the difficulty of understanding the way the competition 'works' in a highly regulated environment where economic aspects like asymmetric information and switching costs are present. Moreover, the global crisis has recently shed light on the regulatory failure and potential contradictions between regulatory intervention and competition policy.

As a result, special attention should be paid to the competition policy application. Based on the recent debates on the implications of competition for banking sector stability, this study try to answer to nowadays questions regarding the controversial interlink between banks and antitrust policies- are banks different or 'special' from a financial stability perspective, describing the three classic areas of competition policy (cartels, mergers and abusing of dominance)?

The main hypothesis will be focused on competition's role regarding the stability of the banking and financial sector in general, focusing mostly on the market structure and how the later (monopoly - oligopoly - or monopolistic competition) may affect or not the stability of banking sector.

\section{Literature review}

Competition in the banking market has been at the center of the policy debate on financial stability. As in other, nonfinancial, markets competition is often seen as prerequisite for an effective banking system. Several theoretical and empirical studies, however, have shed doubts on this proposition, claiming that monopoly rents gives banks higher incentives to invest in relationships with smaller and more opaque borrowers. 
Similarly, theoretical and empirical studies have not come to a conclusive finding on the relationship between banking market competition and stability. The specialty of the banking system from the perspective of stability is a widely recognized idea (see e.g. Goodhart [1987a] and Goodhart et al. [1998]). What is much less debated in the literature is the implications this special status has for market structures and competition policies.

Similarly, not much research work has been dedicated to the implications different bank market structures and degrees of competitiveness have for bank stability and supervisory policies (see also Allen and Gale [2000b] and Canoy et al. [2001]).

\section{Paper's Context}

Changes/Alteration of the banking system structure during the last 20 years, transition from the system with one-level to the existing one, diminution/shrinking of state banks supremacy after the privatization and adoption of a system 100\% own by the private entities, modification of the ex-savings bank behavior after privatization from Raiffeisen Bank, behavior of the banks in groups as per their origin or application of the prisoner's dilemma during the process of determining the yield in the treasury bonds bids, shall be some of the main issues to be consider in this research paper As the central bank is more concerned on the stability of the banking system, antitrust authority is more focused in achieving free and effective competition in this essential chain of the financial sector. But, different objectives/subjects, sometimes controversial/contrary to each other, should not prevent the growth of the stability and competition in the banking market, simultaneously.

\section{Methodology}

In order to test the relationship between stability and competition, we need appropriate measures of both. Bank stability is mostly measured in a negative way, i.e. by considering individual or systemic bank distress.

Systemic banking distress can be broadly defined as periods where the banking system is not capable of fulfilling its inter mediation function (deposit taking, lending, payment services) for the economy effectively anymore. In this paper, we follow the definition by Demirguc-Kunt and Detragiache $(1998,2002)$ who define banking distress as systemic if (i) non-performing assets reached at least 10 percent of total assets at the peak of the crisis, (ii) the fiscal cost of the rescue operations was at least 2 percent of GDP, (iii) emergency measures, such as bank holidays, deposit freezes, blanket guarantees to depositors or other bank creditors, were taken to assist the banking system, or (iv) if large-scale bank nationalizations took place.

\section{Analyses}

\subsection{Relevant market}

The relevant market of the product is the market for treasury bills (short term domestic debt up to 1 year), sub divided in the following:

1. The primary market for treasury bills is the market where parties buy and sell regularly bills offered by the Republic of Albania through the banks that own them.

2. The secondary market for treasury bills branches in two additional sub markets:

a) The secondary inter bank market, where banks buy and sell treasury bills among themselves, and

b) The secondary retail market, which is where investors - physical and judicial persons, resident and non residents - can buy and sell treasury bills directly from the counters of banks and other operators that are licensed to carry such transactions.

The geographical market includes the area in which companies supply and demand goods and services, and where competition conditions are homogenous. Since banks and other financial institutions are present in almost the entire geographical territory of the Republic of Albania, than the latter is established as the respective geographical market.

\subsubsection{Demand side substitution}

Second level banks, financial institutions, other public and private institutions and individuals stand on the demand side 
for treasury bills. The substitution analysis in this case considers other potential investment alternatives for these subjects.

\subsubsection{Supply side substitution}

An alternative to substitute this product form the supply side (t-bills suppliers such as the Ministry of Finance, or the liquidity seeker) are obligations. Obligations in this case include risk free debt titles that mature in periods longer than 1 year (in Albania they have maturities of 2, 5, and 7 years). Regardless of the different maturity terms for these products, we can consider them as substitutes of each other because they all serve the one purpose of financing government debt and are all considered risk free.

\subsection{Market dominance}

Reagarding a recent study of OECD, measuring competition in financial markets is complex due to their peculiar features, such as switching costs. Concentration, among other structural indicators, is not a good proxy for competition.

Albanian Competition Authority like many other agencies use measures of market concentration, such as market shares and $\mathrm{HHI}$, to make an initial assessment of competition, these structural measures are only a first step in analysing whether concentration will create or enhance the exercise of market power.

A dominant position(regarding The European Court of Justice) is presume when a competitor has more than $50 \%$ of market share and must be treated taking into account other factors(barriers of entry, swiching costs, financial performance etc) when a playr hold more than $40 \%$ of market shares.

Dispite the fact that albanian banking system has 16 banks, the dominant player has a strong position as a leader in definming the yield of $\mathrm{T}$ bills.

Tab. 1: Market shares of dominant bank in Albanian T-Bill market

\begin{tabular}{|c|c|c|c|c|}
\hline Years & $\mathbf{2 0 0 5}$ & $\mathbf{2 0 0 6}$ & $\mathbf{2 0 0 7}$ & $\mathbf{2 0 0 8}$ \\
\hline Market shares $\mathrm{X}^{1}$ & $64.01 \%$ & $54.97 \%$ & $44,70 \%$ & $38.7 \%$ \\
\hline
\end{tabular}

Data: Bank of Albania, Ministry of Finance, Compilation of authors

Regarding the most important competitors of the dominant bank, data shows that the second bank has a market share in 20053 time less than dominant bank.

Tab. 2: Market shares of other banks

\begin{tabular}{|l|c|c|c|c|}
\hline Years & $\mathbf{2 0 0 5}$ & $\mathbf{2 0 0 6}$ & $\mathbf{2 0 0 7}$ & $\mathbf{2 0 0 8}$ \\
\hline BKT & $12.88 \%$ & $13.55 \%$ & $16.17 \%$ & $18.3 \%$ \\
\hline Societe General & $1.66 \%$ & $6.09 \%$ & $7.22 \%$ & $8.6 \%$ \\
\hline Tirana Bank & $4.9 \%$ & $4.57 \%$ & $4.67 \%$ & $7.4 \%$ \\
\hline Credins & $1.3 \%$ & $3.2 \%$ & $3.72 \%$ & $1.9 \%$ \\
\hline
\end{tabular}

Data: Bank of Albania, Ministry of Finance, Compilation of authors

If we estimate the most relevant players in T bill market, data shows that the dominant player alone has more market share than all other competitors together(Central bank is excluded from competition in T bill actions).

Tab. 3: Domestic debt holders

Domestic Debt Holders in Purchase Value

\begin{tabular}{|l|r|r|r|r|l|}
\hline & $31,12,2005$ & $31,12,2006$ & $31,12.2007$ & 31.12 .2009 & \\
\hline BO.A & $23.17 \%$ & $22.41 \%$ & $21.90 \%$ & $22.98 \%$ & BOA \\
Raiffeisen Bauk & $42.27 \%$ & $37.21 \%$ & $33.69 \%$ & $35.22 \%$ & Banka Raiffeisen \\
Other Bauks & $25.80 \%$ & $31.76 \%$ & $35.24 \%$ & $31.85 \%$ & Bankat e tjera \\
Non Banks & $1.52 \%$ & $1.93 \%$ & $1.84 \%$ & $2.27 \%$ & Jo Banka \\
Individuals & $7.25 \%$ & $6.69 \%$ & $7.34 \%$ & $7.67 \%$ & Jo Konk+F.Pens BOA \\
\hline
\end{tabular}

Data: Bank of Albania, Ministry of Finance, Compilation of authors

${ }^{1}$ Bank of Albania, Supervision Report, (2005-2008) 


\subsection{Market caracteristics}

\subsubsection{Primary market}

Raiffeisen Bank has inherited a dominant position in the market from the privatization of the former Savings Bank. During the period under investigation, it could be noted that the market has been very dynamic when it comes to those parts of the market that are dominated by its operators.

The primary market shows barriers to entry in terms of the required minimal amount for participation of individuals and the transfer of the counters from the Bank of Albania to the banks of the second level. These measures, taken since 2005, have increased participation costs and entry barriers in the auctions for treasury bills for individuals and businesses alike. Even the International Monetary Fund has been in favor of having individuals and businesses deposit their investment funds for treasury bills in the counters of the Bank of Albania, which is seen mainly as a way to give individuals and SMEs direct access to the primary market.

There is only one seller in this market and that is the Albanian Government. To cover its liquidity demands, the government issues marketable securities. Government domestic debt can be financed through several different instruments. However, the weight of treasury bills in this funding scheme is much greater than the funding weight of other financial debt instruments. This weight, though, has been decreasing for treasury bills, and other forms of debt financing securities have been gaining ground, especially after 2005.

The investigation process from Albanian Competition Authority and the hearing sessions showed that during the investigation period there have been changes in the structure of debt financing instruments, both of short term and long term debt, thereby increasing the weight other securities have on this financing process. These changes are attributed to the financial managing strategies of the Ministry of Finance.

\subsubsection{Secondary market}

Treasury bills are traded in the secondary market and exchanged between banks in the inter bank market, as well as between banks and owners of these bonds in the secondary retail market. According to FSA, there are 5 banks operating in the latter market, and the market itself is not well developed.

The number of branches that RB has within the country is much greater than that of any other banks. Its branches are spread out in the entire territory of the Republic of Albania and the competing power of other banks, given their smaller branching intensity (when compared to RB), is much lower. There are cities where RB is the only bank (option) to invest in treasury bills in the secondary market because other banks either don't have branches in these cities or if they do, they don't offer the service of buying treasury bills for individuals.

Another characteristic of the primary and secondary market for treasury bills is the asymmetry of information. The information presented by banks is incomplete and unclear, thus limiting choice options for clients. This has been a factual observation of the task force under the responsibility of the Secretary of the Competition Authority. In general, from our observations in different banks that offer treasury bills in the secondary market, we can conclude that there is a tendency to lack transparency in terms of information given to clients regarding their options on investing in treasury bills. The lack of informational brochures on treasury bills is especially obvious, and this limits clients' awareness on these instruments.

\section{Main Findings}

During the analysis of the dynamics of the yield for t-bills, we could observe a sudden spike in the yield of treasury bills during the third quarter of 2006, and this was the reason why this investigation process was initiated in the first place.

During the study period we could observe that Raiffeisen Bank has experienced a decrease in market share not only in the market for treasury bills, but in the market for deposits as well.

The evidence and respective analysis of the factors that have affected the report of the thorough investigation process, taken jointly with the claims of the party under investigation and the opinions of the public institutions involved in the supervision of this market, show that:

There is no direct and systemic link between the participation (or lack thereof) of the bank and the dynamics of change in the yield of treasury bills during the auctions held throughout the period under investigation (period when the bank had considerable market power).

Raiffeisen Bank has stated that it has not participated in the auction - which was later followed by an increase in 
the yield - due to lower deposits, higher demand for credit, and its participation in the auctions for 2 year maturity bonds. These factors had caused a decrease in liquidity, which in turn did not allow the bank to participate in the primary market for treasury bills.

The Bank of Albania, in its "Monetary Policy Report for the Second Half of 2006," pg. 27, had stated that the increase for credit demand by the government, coupled with rapid credit issued in ALL denominate loans, had caused a decrease in liquidity in the system, which has been reflected in higher yields for treasury bills.

The commissions applied by Raiffeisen Bank for the transfer of funds from its own accounts to the Bank of Albania are high. According to FSA data from 2008, Raiffeisen Bank charges a commission of $1.2 \%$ to the funds available by individuals for participating in the primary market for treasury bills, while other banks apply a commission of $0.2 \%$ for the same service.

Therefore, keeping in consideration what was stated above, it was not proven that Raiffeisen Bank has abused with its dominant position in the primary and secondary market for treasury bills during the period under investigation.

In the primary market we could observe, from an economic standpoint, high and unjustified commissions charged by Raiffeisen Bank. The bank has expressed its willingness to make adjustments for improving competition and lowering servicing costs for the consumers.

\section{Conclusions}

The main scope of this research is to provide evidence that the competition does not weaken the stability of the banking system, but, it enables a better performance of the banking sector by enhancing the efficiency of the system.

The central banks and the antitrust authorities, instead of trying to address to each other the causes/reasons of restriction of competition resulting from the implementation of prudent monetary policies or jeopardy of the stability as a result of antitrust policies intervention during the investigation of the financial market, should cooperate with other aiming to get a banking system that would be transparent, efficient and sustainable towards the challenges of the competition on rise from the regional, European and global banking.

The recent data of first semester of 2013 shows that the T bill yields is decreasing as a reflection of decreasing the market share of Raiffeisen Bank.

The case of dominant position and behavior of Raiffeisen bank is a very good example for the application of Structure-Behavior-Performance Model for Albanian banking system but the authors will go in depth research taking into account a number of variable such as costs, demand, supply and other aspects beside the market structure and behavior of dominant player.

\section{References}

Bank of Albania, Supervision Annual Report, 2000-2012

European Commission, Inquiry in banking sector; June 2005;

Elena Carletti and Xavier Vives, "Regulation and Competition Policy in the Banking Sector", 2008;

Johannes M. Groeneveld and Wim W. Boonstra, "Competition in a highly concentrated banking sector/ Theoretical, empirical and practical considerations for the Netherlands"/, 2005;

Klaus Schaeck, Martin Čihák, and Simon Wolfe, "Are More Competitive Banking Systems More Stable?", IMF working paper, WP/06/143

Nicola Cetorelli, "Competition among banks: Good or bad?"

Note, Sofika, "Competition in Albanian banking system ", 2006

Thorsten Beck, "Bank Competition and Financial Stability: Friends or Foes?, The World Bank Development Research Group Finance and Private Sector Team June 2008;

OECD roundtable/ Competition, Concentration and Stability in the Banking Sector 2010;

John O.S Ëilson, John Goddard, "Measuring Competition in Banking"

OECD, IMF, Bank of Albania, Albanian Competition Authority, Albanian Ministry of Finance, Statistical Institute etc. 